\title{
COMMUNICATION IN BUSINESS ORGANIZATIONS
}

\author{
Ganesh Prasad Niraula \\ Department of Management, TU, TRM Campus, Birganj
}

\begin{abstract}
Now a day, communication has become central part of management. It has been used by different business houses like sole trading, partnership and joint stock companies in their different managerial and non-managerial activities. Its role is inevitable not only in the business organizations but also in our day to day life. Communication is the transformation of information from one person to another to fulfill common interest. It is the exchange offacts, opinions, ideas suggestions and other information. This paper deals with the relevance and role of communication in business organization.
\end{abstract}

\section{Keywords}

Organization, networks, coordination, e-commerce, telecommunication.

\section{Introduction}

Communication is vital to organizational life. In fact, organizations exist through communication. Without communication, there would be no organizations. It is the vehicle through which the basic managerial functions are carried out. Managers direct organizational activities through communication. They coordinate, plan, organize, motivate, and control through communication. Virtually all actions taken in an organization have been preceded by communication. Thus, communication is an essential ingredient of almost everything a manager does.
The word "communication" is derived from the Latin word "communis" which means common. There is much similarity in the definitions given by various writers. These definitions have many things in common. Communication is described as a process through which one person transmits information to another person through appropriate medium.

The traditional view of communication is the transmission of information from one person to another person. In this view, the effort or result of communication is not considered. Hence, this point of view is not adequate for an effective communication to take place. This is 
an example of one way communication. The sender of information is not sure whether or not the receiver correctly received the message sent. But in the modern view, it is believed that communication process cannot be complete unless the message sent was received and correctly understood.

Effective communication is, thus, the process of sending a message in such way that the message received is as close in meaning as possible gtho $_{\text {the }}$ message intended (Griffin, 2009). To communicate effectively, a person or a group has to try to see and feel as the other person or group sees or feels. This does not mean that people or groups always agree but that they understand the others' point of view. They listen to one another. It may be a politician with people, a manager with employees, a teacher with students, but in all cases good communication is possible only if both parties feel at ease and understand each other.

These three approaches are simply the components of the total communication process (Chaudhary, 2008). They have their own relevance to different situations. For business correspondence and oral communication, the message is very important. Hence, the message has to be constructed and delivered properly. Transmission of the message is vital in group or interpersonal interactions. Communication has no meaning if it is not understood properly. Hence, the sender must ensure "feedback" that the receiver gets the message as intended. All these approaches to communication are important. The message sent, its proper transmission, and its proper understanding makes the communication process complete and effective. We can thus conclude that communication is:

A process which involves people, information is transmitted from one part to another, an exchange of information between a sender and a receiver in which both of the parties share the meaning of the message, it is a two way process between individuals or groups and it is a means, not an end.

\section{Relevance of communication in business organization}

In business organizations, there are three levels of management: top level, middle level, and lower level. The top level management formulates policies, programs and strategies that needs sufficient quantity of data and information for that the top level management needs communication. Similarly, middle level management formulates mid-term strategies and programs that also need information and data for that they need communication. Similarly the lower level management formulates the programs and strategies for day-to-day operations that also need communication.

For ongoing directions a two way communication system is essential. For that matter, the entire process of direction, coordination and control in a business organization revolves around communication. Direction itself is effective only when there are two way communications all around. In fact, according to Drucker (1954), 6o percent of management problems are caused fully or partially by faulty management communication.

For effective communication, the process of communication must be understood. Communication does not mean merely passing on a message - top-down or bottomup. It includes understanding of the message sent by recipient, as intended by the sender. If the message sent by the sender has not been understood by the receiver as was intended, no communication has taken place. The receiver, similarly, should seek clarification and confirmation of his understanding for effective communication. Yet, in real life this simple point is often ignored. The relevance of communication can be described with the help of following points: 
Successful operation of business

For successful performance in business operation internal and external communications play a vital role. Since, the business organizations have to make a good relationship with the parties located within the internal and external environment, such as departmental managers supervisors and foremen of own organization and investors, customers, government and general community of outside the organization.

\section{Basis of managerial function}

Communication is the basis for implementing all the managerial functions. In absence of communication, all the managerial functions become ineffective. Without communication the functions of management like planning, organizing staffing, leading and controlling have no application.

\section{Prompt decision and implementation}

As it is said 'whatever a manager does, he does through decision making' for which the manager needs various types of data, information and facts. Managers can be a successful decision maker if he gets information through effective communication.

\section{Bridge between employees and managers}

The main duty of a manager of the business organization is to create a healthy environment for all the employees. Through communication the manager transmits information about policies and programmes of organization precisely to the employees. Similarly, the manager gets their suggestions complaints and opinions through communication. In this way communication becomes a bridge between employees and the managers.

\section{Eliminates misconception}

Every organization wants maximum production at the minimum cost, which determines the firm's success and existence, to achievethisobjectiveeffective communication is required. Effective communication establishes good coordination between physical, financial and human resources of the organization. Communication actually, eliminates all misconception, bad things and opinions among employees and enhances good relationships on them. This enables the organization to produce maximum output at the minimum cost.

\section{Role of communication in organization}

Good communication is essential for managerial effectiveness. A large portion of a manager's time is spent in communicating, explaining plans, schedules, policies, procedures to subordinates; briefing the upper management about the progress and problems; and informing outside parties about the organization. Managers lead meetings and talk one-to-one. They participate in conferences and consultative bodies formed by the government. Today, electronic mails have dominated the business scene. All these activities of managers involve communication. Hence, communication skills are essential for managers.

Managerial functions like planning, organizing, leading and controlling all involve communication. Not only this, organizational functions like decisionmaking, coordination, interpersonal relations, etc. also need communication. In fact, the total organizational structure is tied to communication system. Moreover, the process of organizational change and development and organizational effectiveness also involve communication. Communication is, therefore, of utmost significance in modern organizations.

Mintzberg (1973) studied the working of business executives in organizations. It was found that nearly 78 percent of their time was 
spent in communication-related activities like attending meetings, attending visitors, receiving telephone calls, and touring different offices under them. Only 22 percent of their time was spent for "desk-work". He found that not only top executives were busy in communicating, but also the middle and lower level managers were involved heavily in communication with others. Hence, managers at all level of the organization spend considerable time in communication.

Today companies have enough space for formal and informal meetings to get together whenever the need for such meeting arises. Business organizations, encourage team or group work. Therefore, the latest management thinking is to facilitate communication throughout the organizations. Without free, frank, and open communication, the functioning of work teams, problem-solving teams, or self-management work teams cannot be effective.

These days business organizations are in the grip of new communication technologies. This technological development is both an opportunity and a constraint. It is an opportunity for those enterprises, which make its use effectively and efficiently. It is a constraint for those enterprises, which cannot use it or afford it.

Some forms of mail transmitted electronically have been available for years- the telegram, the mailgram, the cablegram. Messages of these kinds travel faster than postal messages. Currently, facsimile (fax) and e-mail transmission represent a step forward in the use of electronic mail. Any kind of printed or typed document can be transmitted over regular telephone lines to anyone having a similar machine.

Now business enterprises can do their dayto-day business electronically. E-commerce practices have grown considerably. In future, this is going to grow even further. Internet service and web sites have revolutionized the transmission of information. These communication networks are extremely reliable. These technologies have contributed to the emergence of "paperless office". Today, with right e-mail tools and accessories, printers and envelopes have become almost unnecessary. Managers can now send and receive official letters and memos from their different offices through computer terminals.

The advent of low-cost cellular phones and high-power mobile telephones has broadened the scope of telecommunicating. Computers are also facilitating the increase in telecommunication. Virtual offices are the realities today. It is an office in which people can work anywhere in car, at home, etc as long as they have the tools to communicate.

High cost of air travel, hotel rooms, food, and time lost while traveling have contributed to the use of teleconferencing in business. Electronically held conferences are very effective face-to-face live meetings. These services are now available to business enterprises for their use. In this way, the facial expression and gestures that add so much to communication are apparent. Thus, the challenge for managers today is that they should have the ability and skill to communicate in new and efficient ways. The movement toward informationalization and knowledge-based societies are expected to change the functioning of organizations.

Hence, we can say that the role communication is pivotal. Without using modern means of communication, the operation of business activities is almost impossible because many managers and assistants of modern organizations are addicted to the communication equipments.

\section{Conclusion}

Communication is a vital element in modern world of global competition because every business entity located in the interiors and big metropolis is affected by communication. 
Even a layman in the village uses the different equipments of communication. Every business organization should target all types of individual in the society so that they can sell their products easily in the market. Nowa-days business means using different types of communication modes that disseminate information to the different category of stakeholders of business organizations. The manager is the one who collects information from outside world as monitor, filters them and disseminates to the different departments and units within the organization as well as outside world as required. As far as communication is concerned no communication takes place, unless the receiver of message understands as intended by the sender.

\section{References}

Chaudhary, S. (2008). Project management. New Delhi: Tata McGraw-Hill Publishing Company Limited.

Drucker,P.F.(1954). The practice of management. New York: Harper \& Row.

Griffin, Ricky W. (2009). Management.New Delhi: AITBS Publishers and Distributors.

Mintzberg, H. (1973).The nature of managerial work. New York: Harper and Row. 